\title{
The geochemistry of Tibetan lavas: geodynamic implications
}

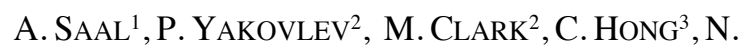 \\ NIEMI $^{2}$, S. MALLICK ${ }^{1}$ \\ ${ }^{1}$ DEEPS, Brown University, Providence, RI 02912, USA \\ ${ }^{2}$ DEES, University of Michigan, Ann Arbor, MI 48109, USA \\ ${ }^{3}$ IEE, Chinese Academy of Sciences, Xi'an 710075, China
}

The continental lithosphere is created and modified at convergent plate boundaries through complex, and interdependent, tectonic and magmatic processes. One approach to unraveling interactions between the continental lithosphere and asthenosphere in subduction zones is through the evolution of pre-, syn- and post-collisional mafic volcanism (i.e., $\mathrm{MgO} \geq 6 \mathrm{wt} \%$ ). Here, we evaluate a compilation of published geochemical and geochronological data for late Mesozoic and Cenozoic magmas from the IndoEurasian collisional orogen. Based on compositional, age and spatial patterns of mafic lavas $(\mathrm{MgO} \geq 6 \mathrm{wt} \%)$, we delineate two distinct periods of Tibetan mafic magmatism, with a major compositional change occurring at roughly 46 Ma. Early (pre-46 Ma) mafic lavas erupted only in central and southern Tibet, and were generated by melting within the mantle wedge during the northward subduction of the NeoTethyan oceanic slab. Late (post-46 Ma) mafic lavas were produced by the partial melting of metasomatized subcontinental lithospheric mantle. The latter group is spatially restricted to central Tibet between 46-30 Ma. After $30 \mathrm{Ma}$, lavas derived from melting of the lithospheric mantle expanded both northward and southward, eventually encompassing the entire Tibetan Plateau by 20 Ma. These observations suggest that melting of the lithospheric mantle beneath Tibet initiated earlier, and was more widespread, than previously thought. Our results also suggest that widespread melting of the mantle lithosphere across Tibet post-dates the cessation of upper crustal shortening in northern Tibet at $\sim 30$ $\mathrm{Ma}$, and precedes the initiation of crustal extension at $\sim 15-10$ Ma. We suggest that plateau-wide melting of metasomatized subcontinental mantle lithosphere initiated following the collision of India with Eurasia, at $46 \mathrm{Ma}$. This melting was induced by detachment of the Neo-Tethyan slab concomitant with thinning of the continental mantle lithosphere. Such melting has continued until the present, with the exception of volcanic quiescence in south-central Tibet since $\sim 10$ Ma due to the underthrusting of Indian lithosphere beneath Eurasia. We propose that mantle lithosphere thinning and removal has been part of a continuum melting process during the IndoAsian orogen that reflects an evolution from mantle wedge to mantle lithosphere melting accompanying the transition from subduction to collision. 